IJCCS (Indonesian Journal of Computing and Cybernetics Systems)

Vol.13, No.3, July 2019, pp. 251 262

ISSN (print): 1978-1520, ISSN (online): 2460-7258

DOI: https://doi.org/10.22146/ijccs.46625

\title{
DSS for "E-Private" Using a Combination of AHP and SAW Methods
}

\author{
Ni Komang Yanti Suartini*1' I Made Agus Wirawan², Dewa Gede Hendra Divayana ${ }^{3}$ \\ ${ }^{123}$ Informatics Education Study Program, Informatics Department, Undiksha, Bali, Indonesia \\ e-mail: *11yantisuartini11@gmail.com, ${ }^{2}$ imade.aguswirawan@undiksha.ac.id, \\ hendra.divayana@undiksha.ac.id
}

\begin{abstract}
Abstrak
Les privat adalah pendidikan nonformal yang dibutuhkan untuk membantu menunjang proses belajar siswa. Banyak sistem les privat yang sudah berkembang, dimana pemilihan guru les privat dilakukan dengan proses filtering. Namun proses filtering saja kadang tidak sesuai dengan kebutuhan dan keinginan siswa. Selain proses filtering, E-Privat yang dikembangkan juga menggunakan konsep Sistem Pendukung Keputusan (SPK) yaitu kombinasi metode AHP dan SAW. Kedua metode pada konsep SPK tersebut digunakan untuk mendukung solusi dalam pengambilan keputusan pemilihan guru les privat. Metode AHP digunakan untuk mencari bobot pada setiap kriteria, dan dirangking dengan metode SAW. E-Privat bertujuan untuk membantu orang tua/siswa dalam memilih guru les privat yang sesuai dengan kebutuhan dan keinginan siswa dengan melibatkan multi kriteria dan berbagai alternatif. Sistem ini juga dikembangkan untuk membantu guru les privat dalam mendapatkan peluang mengisi les privat. Pengembangan sistem sudah berhasil dan layak untuk digunakan berdasarkan hasil uji black box dan white box, dengan tingkat akurasi mencapai $87 \%$ dan uji respon pengguna menggunakan metode SUS menunjukkan hasil persentase $92.08 \%$ dengan kategori best imaginable.
\end{abstract}

Kata kunci-Guru Les Privat, Sistem Pendukung Keputusan, AHP, SAW.

\begin{abstract}
Private tutoring is non-formal education and it is needed to help students in learning. There is already a tutoring system developed where the selection of private tutors is done by the filtering process. However, the filtering process is not suitable for the needs and desires of students. Besides the filtering process, the E-Privat developed also uses the concept of Decision Support System (DSS), namely a combination of AHP and SAW methods. The two methods in the DSS concept are used to support solutions in decision making for private tutors. AHP method is used to find the weights in each criterion, and the ranking calculation with the SAW method. E-Privat aims to help parents/students in choosing private tutors that are suitable for the needs and desires of students by involving multi-criteria and various alternatives. This system is also developed to help private tutors to get the opportunity to fill out private lessons. System development has been successful and feasible to use based on the results of the black box and white box testing, with an accuracy of $87 \%$ and the user's response test which is used by the SUS method shows a percentage $92.08 \%$ with the best imaginable category.
\end{abstract}

Keywords—Private Tutors, Decision Support System, AHP, SAW.

Received June 15 $5^{\text {th }}, 2019 ;$ Revised July $18^{\text {th }}, 2019$; Accepted July $19^{\text {th }}, 2019$ 


\section{INTRODUCTION}

Student learning processes can be carried out both in school and outside of school. Learning outside of school through non-formal education institutions can provide additional knowledge, skills, and experience more fully [16]. Non-formal education can be done through private tutoring. Private tutoring is the most effective non-formal education because the tutor can see and improve students abilities in a focused and appropriate manner [14]. This statement shows that private lessons have an important role in education and can support the success of student learning.

But the results of observations that were done from elementary, junior high, and senior high school showed that $100 \%$ of respondents who need private tutoring are still constrained by private tutoring information that matches the desired and needed criteria. The results of observations made from tutors showed that $100 \%$ of respondents who wanted to fill out private lessons were still constrained by information on the needs of private lessons available in the community. Observations were also carried out by direct interviews with two private tutors' providers that showed (1) the system still uses a conventional system, in the form of notebooks for each student and tutor documents, (2) general criteria for tutor selection are based on education, experience, costs, discipline, and how to teach, (3) needed accuracy for the tutor selection in ensuring the satisfaction of private tutors.

To overcome the existing problems, the researcher needs a solution that can (1) help prospective private tutors in quick and appropriate decision making in the selection of private tutors, (2) be able to provide various alternatives in decision making, (3) can help private tutors to fill out private tutoring. In the selection of private tutors involving various kinds of criteria that will influence the solutions is taken to solve the problem. To support solutions in helping students to facilitate decision-making based on predetermined criteria can use the Decision Support System (DSS) $[5,8]$. The selection of private tutors requires a ranking process that can involve multi-criteria to get the best alternative from several available alternatives. The DSS method which can be used in ranking processes involving multi-criteria namely Simple Additive Weighting (SAW) [7,10]. SAW is the simplest method and can handle costs and benefits simultaneously [1]. The SAW method is also used because it is faster, more precise and more accurate than using the Technique for Others Solution (TOPSIS) and the Weighted Product (WP) $[6,11,13]$. But the SAW method cannot manage qualitative and the necessity of giving weight to each criterion before calculating alternative ranking becomes a weakness in the use of the SAW method [13]. To process qualitative and weighting each criterion can be done using the Analytical Hierarchy Process (AHP) method $[1,12,15]$. The concept eigenvector in the AHP method can be used in the priority weighting process of each criterion based on the pairwise comparison matrix [4]. The combination of using the AHP method to find the weight values to be used in the SAW method for ranking turned out to have more objective results than direct weighting $[2,13]$.

Based on the explanation, the researcher conducted a study entitled "Decision Support Systems for the Selection Private Tutoring (E-Private) Using a Combination of Analytical Hierarchy Process (AHP) and Simple Additive Weighting (SAW) methods". AHP is intended to find the weight of each criterion and SAW is intended to rank the alternatives. The facilities that will be offered on the system that will be developed are (1) helping to provide recommendations for the best choices in getting tutors based on the criteria desired and needed by prospective private tutors, (2) helping to provide detailed information of private tutors, (3) helping in promoting private tutoring. The system that will be developed is based on the website by using responsive design to be suitable to be accessed from various types of devices. So this research is expected to help bring together students-tutors and provide the best private tutor recommendations.

IJCCS Vol. 13, No. 3, July 2019: 251-262 


\section{METHODS}

The research method used type of research and development ( $R \& D$ ) with the system development Life Cycle (SDLC) method. The model was waterfall. This model was first introduced by Winston Royce around the 1970s. The waterfall model was a classic model that was systematic, sequential in building software [9]. The stages of waterfall model was shown in Figure 1 .

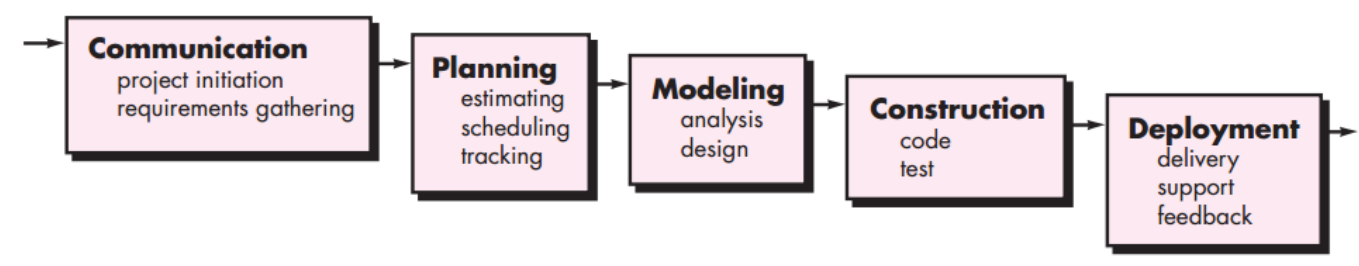

Figure 1 Stages of Waterfall Model

The first stage was communication, at this stage, the researchers get the criteria used in choosing private tutoring teachers namely the type, of course, gender, teaching location, education, experiences, cost, discipline, and how to teach. The criteria were obtained through the collection of information by conducting interviews in two private tutoring areas and the dissemination of questionnaires to 56 students and 28 tutors.

The next stage was planning, the researcher performs analysis of requirements used to design the system. At this stage, researchers conduct analysis based on literary studies to determine the criteria that will be filtered and the criteria that will go through the DSS method. Based on the analysis, the type of course, gender, teaching location went into the filtering phase, while the education, experiences, cost, discipline, and how to teach entered into the DSS method. Also, researchers conduct analyses in determining the methods used in the selection of tutor private tutors. The methods used are AHP and SAW methods. AHP method is used in the process of weight because this method can provide more objective results and able to manage data that is qualitative. AHP method combined with the SAW method in the stage, because the SAW method can manage data of cost and benefit simultaneously.

The next stage was modeling, the researcher designed a system that helped in defining the entire system architecture. In producing decision support, the first step to be carried out on the system was to conduct a filtering process on the type of course, gender, and teaching location. The next step was weighting using the AHP method, users can choose from 5 choices of existing criteria, namely education, experience, cost, discipline, and how to teach. After all the weights for each criterion in all alternatives were obtained by the AHP method, then the SAW method would rank the available alternatives. The calculation design was explained in the following flowchart design was shown in Figure 2. 


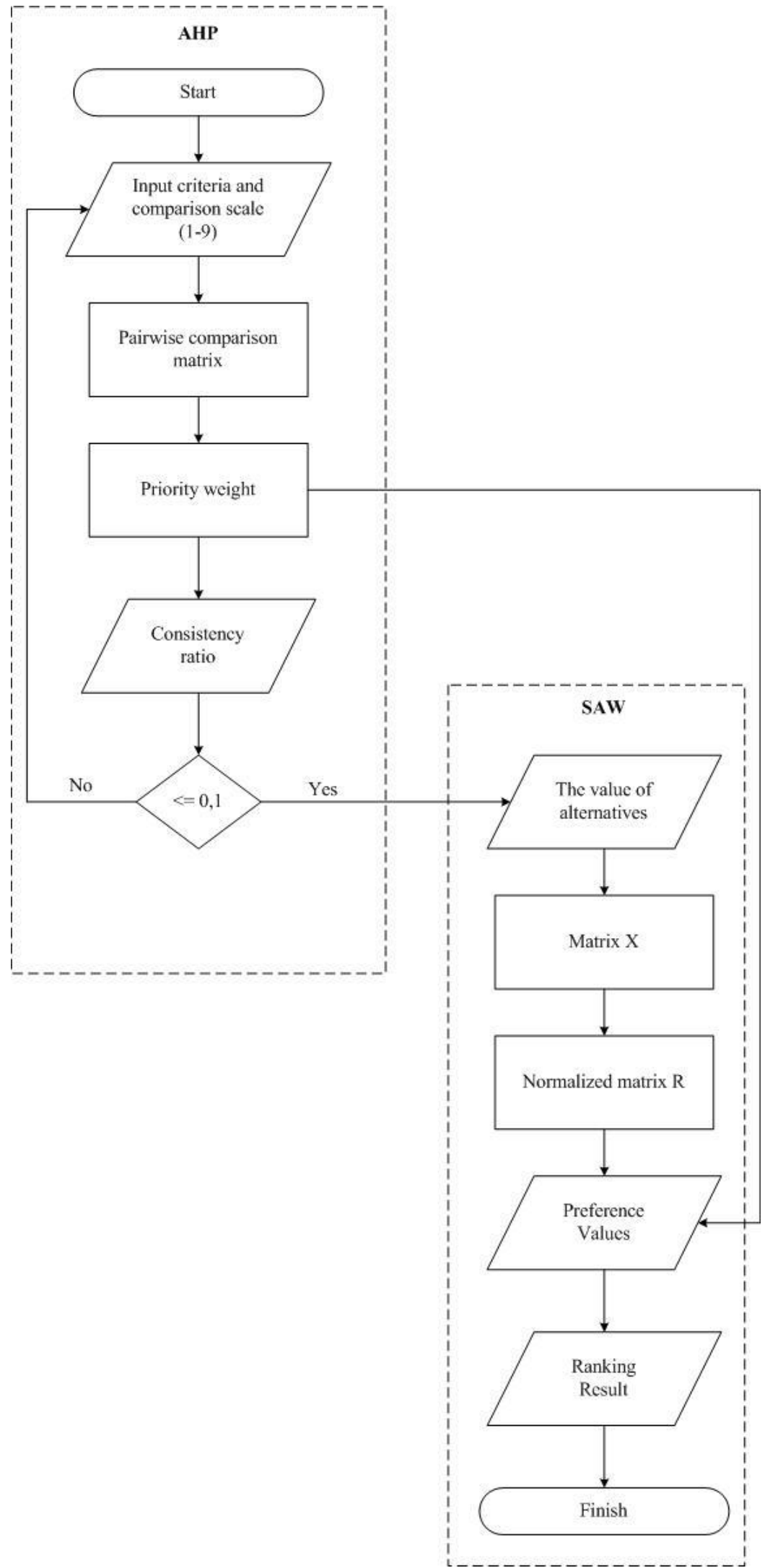

Figure 2 Flowchart Design of Calculation was using a Combination AHP and SAW Methods 
In the AHP process, the user could input criteria that would be used from 5 choices of existing criteria and gave a scale weight comparison 1-9 (Saaty Scale). If the user only used 1 criterion, it was not necessary to give a weighted comparison scale, because the direct weighting value was 1 . Then the weight values entered would form a comparison matrix according to the number of criteria entered. In the comparison matrix, the number of each criterion was used, then it would be divided by the number of criteria used and produce priority weights. After obtaining priority weights, the next step was to calculate the consistency ratio to see whether the paired comparisons were fairly consistent or not. If $\mathrm{CR}>0.1$ the pairwise comparison matrix must be corrected. If $\leq 0.1$, the stage was continued to SAW process to make matrix X from the value of each alternative. Next, identify criteria which were cost and benefit then a normalized matrix R was formed. So, the final results calculated the preference values obtained from the weight of the results of the AHP method with the normalized matrix R by using the SAW method.

In the AHP process, the user could input criteria that would be used from 5 choices of existing criteria and gave a scale weight comparison 1-9 (Saaty Scale). The Saaty Scale was shown in Table 1.

Table 1 Saaty Scale

\begin{tabular}{|c|l|}
\hline Intensity of importance & \multicolumn{1}{|c|}{ Description } \\
\hline 1 & Equal (equally important) \\
\hline 3 & Moderate (moderately/weakly/slightly more important) \\
\hline 5 & Strong (strongly more important) \\
\hline 7 & Very strong (very strongly/demonstrably more important) \\
\hline 9 & Absolute (extremely/absolutely more important) \\
\hline $2,4,6,8$ & Compromises/between \\
\hline
\end{tabular}

If the user only used 1 criterion, it was not necessary to give a weighted comparison scale, because the direct weighting value was 1 . Then the weight values entered would form a comparison matrix according to the number of criteria entered. In the comparison matrix, the number of each criterion was used, then it would be divided by the number of criteria used and produce priority weights. After obtaining priority weights, the next step was to calculate the consistency ratio to see whether the paired comparisons were fairly consistent or not. If CR > 0.1 the pairwise comparison matrix must be corrected. If $\leq 0.1$, the stage was continued to SAW process to make matrix $X$ from the value of each alternative. Next, identify criteria which were cost and benefit then a normalized matrix $\mathrm{R}$ was formed. So, the final results calculated the preference values obtained from the weight of the results of the AHP method with the normalized matrix R by using the SAW method.

The next stage was construction, the researcher performs the code implementation/coding which was a design translator in a language that can be recognized by the computer. Researchers use programming languages PHP, HTML5, CSS3, MySQL, XAMPP version 3.2.2 as database server package, text editor Sublime Text 2, and Laravel Framework 5.8. In the construction phase, researchers also conducted tests to test the feasibility of the system. The tests are black-box testing, white-box testing, accuracy testing, and user response testing. The last stage was deployment, researchers implemented the system to users.

\section{RESULTS AND DISCUSSION}

The calculation by combining AHP and SAW methods were explained as follows. The value of alternatives was shown in Table 2 . 
Table 2 The Value of Alternatives

\begin{tabular}{|c|c|c|c|c|c|c|}
\hline No & Tutors & Education & Experience & Cost & Discipline & How to Teach \\
\hline 1 & Tutor A & 3 & 12 & 75000 & 3 & 5 \\
\hline 2 & Tutor B & 1 & 16 & 20000 & 4 & 5 \\
\hline 3 & Tutor C & 2 & 4 & 50000 & 5 & 4 \\
\hline
\end{tabular}

- Assessment of educational criteria:

1: University students

2: Associate Degree

3: Bachelor degree

4: Master degree

5: Doctoral degree

- Assessment of experience criteria, teaching experience calculated in the month.

- Assessment of cost criteria, the cost (Rupiah) shown every one-time teaching

- Assessment of discipline and how to teach criteria :

1: Very less good

2: Not good

3: Good enough

4: Good

5: Excellent

Priority weight calculation by using AHP method:

a. Compile hierarchy, was shown in Figure 3.

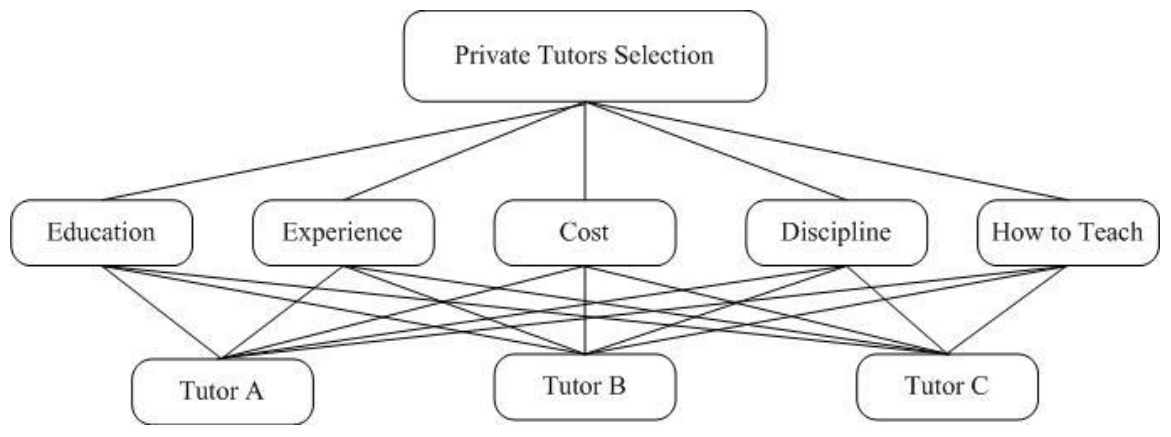

Figure 3 Hierarchy

b. Determine the pairwise comparison matrix

The stage pairwise comparisons were carried out of criteria with a comparison scale 1-9 (Saaty Scale). The pairwise comparison matrix was shown in Table 2.

Table 3 The Pairwise Comparison Matrix

\begin{tabular}{|c|c|c|c|c|c|}
\hline Criteria & Education & Experience & Cost & Discipline & How to Teach \\
\hline Education & 1 & 2 & 7 & 5 & 7 \\
\hline Expeerience & $1 / 2$ & 1 & 2 & 7 & 5 \\
\hline Cost & $1 / 7$ & $1 / 2$ & 1 & 2 & 7 \\
\hline Discipline & $1 / 5$ & $1 / 7$ & $1 / 2$ & 1 & 2 \\
\hline How to teach & $1 / 7$ & $1 / 5$ & $1 / 7$ & $1 / 2$ & 1 \\
\hline Total & 1.99 & 3.84 & 10.64 & 15.5 & 22 \\
\hline
\end{tabular}


Implementation system for weighting was shown in Figure 4.

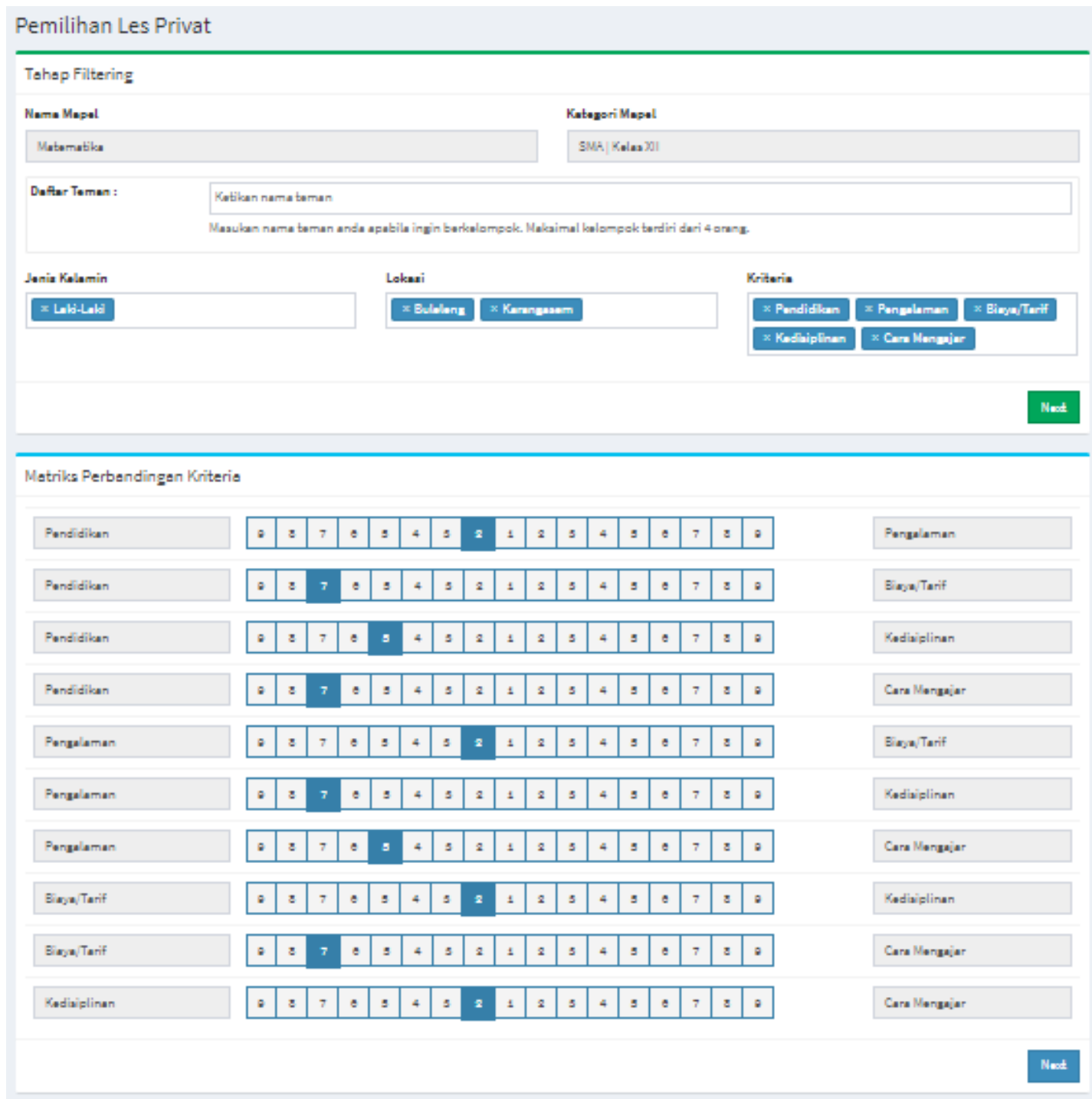

Figure 4 Implementation System for Weighting

c. Determine priority scale, was shown in Table 4.

Table 4 Priority Scale

\begin{tabular}{|c|c|c|c|c|c|c|c|}
\hline Criteria & Education & Experience & Cost & Discipline & $\begin{array}{c}\text { How to } \\
\text { teach }\end{array}$ & Total & Priority \\
\hline Education & 0.50 & 0.52 & 0.66 & 0.32 & 0.32 & 2.32 & 0.46 \\
\hline Expeerience & 0.25 & 0.26 & 0.19 & 0.45 & 0.23 & 1.38 & 0.28 \\
\hline Cost & 0.07 & 0.13 & 0.09 & 0.13 & 0.32 & 0.74 & 0.15 \\
\hline Discipline & 0.10 & 0.04 & 0.05 & 0.06 & 0.09 & 0.34 & 0.07 \\
\hline How to teach & 0.07 & 0.05 & 0.01 & 0.03 & 0.05 & 0.22 & 0.04 \\
\hline Total & 1.00 & 1.00 & 1.00 & 1.00 & 1.00 & 5.00 & 1.00 \\
\hline
\end{tabular}


d. Determine consistency ratios, was shown in Table 5 .

Table 5 Consistency Ratios

\begin{tabular}{|c|c|c|c|c|c|c|}
\hline Criteria & Education & Experience & Cost & Discipline & How to teach & Total \\
\hline Education & 0.46 & 0.55 & 1.04 & 0.34 & 0.30 & 2.70 \\
\hline Expeerience & 0.23 & 0.28 & 0.30 & 0.48 & 0.22 & 1.50 \\
\hline Cost & 0.07 & 0.14 & 0.15 & 0.14 & 0.30 & 0.79 \\
\hline Discipline & 0.09 & 0.04 & 0.07 & 0.07 & 0.09 & 0.36 \\
\hline How to teach & 0.07 & 0.06 & 0.02 & 0.03 & 0.04 & 0.22 \\
\hline
\end{tabular}

This calculation was used to ensure that the consistency ratio $(\mathrm{CR}) \leq 0.1$. But if $\mathrm{CR}>$ 0.1 the pairwise comparison matrix must be corrected. Total of each criterion was shown in Table 6.

Table 6 Total of Each Criterion

\begin{tabular}{|c|c|c|c|}
\hline Criteria & Total & Priority & Value = Total/Priority \\
\hline Education & 2.70 & 0.46 & 5.81 \\
\hline Expeerience & 1.50 & 0.28 & 5.43 \\
\hline Cost & 0.79 & 0.15 & 5.32 \\
\hline Discipline & 0.36 & 0.07 & 5.30 \\
\hline How to teach & 0.22 & 0.04 & 5.11 \\
\hline \multicolumn{3}{|c|}{ Total Value } \\
\hline
\end{tabular}

$\lambda \max =\frac{\text { Total Value }}{\text { Total of criteria }}=\frac{26.96}{5}=5,39$

$\mathrm{CI}=\frac{\Lambda \max -\mathrm{n}}{n-1}=\frac{5,39-5}{5-1}=0,1$

$\mathrm{IR}=1,12$ (because it used 5 criteria)

$\mathrm{CR}=\frac{C I}{I R}=\frac{0,1}{1,12}=0,09$

Value of $\mathrm{CR}<0.1$, the comparison was consistent and calculation was continued on the ranking process with SAW method.

Alternative ranking by using SAW method:

e. Decision matrix $\mathrm{X}$, as below

$$
\left[\begin{array}{ccccc}
3 & 12 & 75000 & 3 & 5 \\
1 & 16 & 20000 & 4 & 5 \\
2 & 4 & 50000 & 5 & 4
\end{array}\right]
$$

f. Determine normalized matrix by identifying cost and benefit criteria. Cost was cost, and education, experience, discipline, values of how to teach were benefit. The following calculation was obtained:

$$
\begin{aligned}
& \mathrm{r}_{11}=\frac{3}{\operatorname{MAX}\{3 ; 1 ; 2\}}=1 \\
& \mathrm{r}_{12}=\frac{12}{\operatorname{MAX}\{12 ; 16 ; 4\}}=0.75 \\
& \mathrm{r}_{13}=\frac{\operatorname{MIN}\{75000 ; 20000 ; 50000\}}{75000}=0.27
\end{aligned}
$$




$$
\begin{aligned}
\mathrm{r}_{14} & =\frac{3}{\operatorname{MAX}\{3 ; 4 ; 5\}}=0.6 \\
& =\frac{5}{\operatorname{MAX}\{5 ; 5 ; 4\}}=1
\end{aligned}
$$

etc, and normalized matrikx R.

$\mathrm{R}=\left[\begin{array}{lllll}1.00 & 0.75 & 0.27 & 0,60 & 1,00 \\ 0.33 & 1.00 & 1.00 & 0,80 & 1,00 \\ 0.67 & 0.25 & 0.40 & 1,00 & 0,80\end{array}\right]$

g. The final result of preference value $\left(\mathrm{V}_{\mathrm{i}}\right)$

$\mathrm{V}_{1}=0.46 * 1.00+0.28 * 0.75+0.15 * 0.27+0.07 * 0.60+0.04 * 1.00$

$$
=0.79
$$

So, the final result of preference value for each alternatives was shown in Table 6 .

Table 7 Preference Values

\begin{tabular}{|c|c|c|}
\hline Tutors & Preference & Rank \\
\hline Tutor A & 0.79 & 1 \\
\hline Tutor B & 0.68 & 2 \\
\hline Tutor C & 0.54 & 3 \\
\hline
\end{tabular}

The Calculation result on the system was shown in Figure 5.

\section{Nilai Bobot Prioritas dari Setiap Kriteria yang Anda Pilth}

\begin{tabular}{|c|l|c|}
\hline No. & Kriteria & Nilai \\
\hline 1 & Pendidikan & 0.46 \\
\hline 2 & Pengalaman & 0.28 \\
\hline 3 & Biaya/Tarif & 0.15 \\
\hline 4 & Kedisiplinan & 0.07 \\
\hline 5 & Cara Mengajar & 0.04 \\
\hline
\end{tabular}

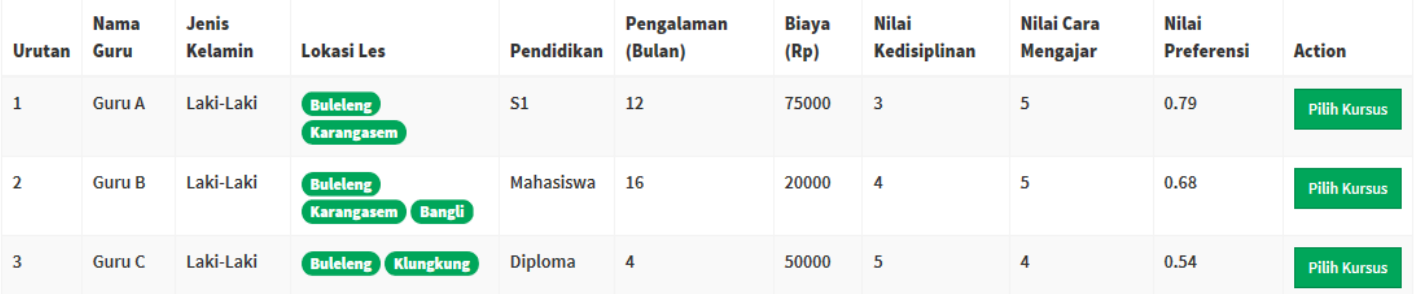

Figure 5 Calculation Result on the System

The results of calculations on the system were very accordance with manual calculations. The testing was also done by some tests such as black box testing, whitebox testing, accuracy testing, and user response testing.

a. Black-box testing

In this test there were 91 test cases and the results of the software response were $100 \%$ as expected. The result showed that the system had worked very well in accordance with existing functional requirements and found no bugs or errors that caused the system error. 
b. White-box testing

The result of the test showed that the flow of the algorithm that had been implemented in the system supporting the decision of the selection of "E-Private" private tutors by using a combination of AHP and SAW methods ran very well.

\section{c. Accuracy testing}

The researcher made a comparison of the results of the selection through manual choices and choices generated from the system. The researcher used 15 respondents consisting of parents and students. The first thing the respondents did was to fill out the conformity test questionnaire, the respondents chose the criteria used and chose one of the private tutors in the questionnaire. After filling out the questionnaire, respondents used the system with access to login as students, then the researchers compared the results of the tutor selection manually with the results recommended on the system. The accuracy test results obtained showed a percentage of $87 \%$.

Accuracy $(\%)=\left(\sum\right.$ valid test $/ \sum$ total test $) \times 100 \%=13 / 15 \times 100 \%=87 \%$.

The achievement of the test results was not perfect, because of the limited number of respondents the researchers used and some constraints from respondents when inputting the comparison scale, because if the consistency value $>0.1$ then the comparison matrix input must be repeated.

\section{d. User response testing}

The test of user response was using the SUS method. This test involved 30 respondents (15 respondents consisting of parents and students whereas, 15 respondents consist of private tutors). Before filling out the questionnaire, respondents had to firstly try to use the E-Privat that had been developed then the respondent responded according to the statement on the questionnaire. User response data gave a percentage of $92.08 \%$ with the best imaginable category and showed that the system supporting the decision of the selection of "E-Private" private tutors with a combination of AHP and SAW methods was acceptable and feasible to use.

The achievement of the results of the user response testing that had been done was not perfect, because the system developed had a different concept in general in conducting the selection of private tutors. So, understanding was needed to the respondents, especially in the process of granting a matrix comparison scale.

\section{CONCLUSIONS}

The decision support system for the selection of private tutor "E-Privat" by using a combination of AHP and SAW methods developed based on the web which was capable of managing student data, tutor data, course data, draft tutor of teaching, draft of student learning, balances, assessments, and provided results of decision support in the selection of private tutors. In addition, the first stage of selecting private tutors was filtering on courses, gender, and teaching location. Then, selecting criteria that students should choose which consisted of 5 existing criterias such as education, experience, costs / rates, discipline, and how to teach. After that, proceed with weighting by using the AHP method combined with the SAW method for alternative ranking based on the choice of criteria entered in the system. System development had been declared $100 \%$ successful based on the white box and black box test results. Accuracy test reached percentage $87 \%$. User response test reached a percentage $92.08 \%$ with best imaginable category and showed that the system was acceptable and feasible to use.

In the weighting process of this study, the researcher calculated a consistency ratio to measure the level of consistency in giving a scale to a paired comparison matrix, so that if the $\mathrm{CR}>0.1$ then the user must re-enter the scale in the pairwise comparison matrix. It was expected that the next developer will use the eigenvector concept in the AHP method in the process of weighting each criterion based on the pairwise comparison matrix or using other

IJCCS Vol. 13, No. 3, July 2019: 251-262 
decision support system methods to compare the results obtained. So, the appropriate method will be found with higher accuracy for the case of private tutor selection and be able to use the number of respondents during testing. Besides, it is necessary to conduct user experience testing (UX) on the system supporting the decision of the "E-Private" private tutor selection by combining the AHP and SAW methods.

\section{REFERENCES}

[1] Astradanta, M., Wirawan, I. M. A., \& Arthana, I. K. R. (2016). Pengembangan Sistem Penunjang Keputusan Pemilihan Tempat Kuliner dengan Menggunakan Metode AHP dan SAW (Studi Kasus: Kecamatan Buleleng). Kumpulan Artikel Mahasiswa Pendidikan Teknik Informatika(KARMAPATI), 5(2), 1-11 [Online]. Available: https://ejournal.undiksha.ac.id/index.php/KP/article/viewFile/8205/5473. [Accessed: 28Nov-2018]

[2] Bernadifta, E. Y., Eliantara, F., Dwi K, F., \& Sulistiowati, F. (2016). Sistem Pendukung Keputusan Penerimaan Pegawai Menggunakan Metode Analitycal Hierarchy Process (AHP) dan Simple Additive Weighting (SAW). PTIIK-UB, 2(1), 1-7.

[3] Indra Herman Firdaus, Gunawan Abdillah, F. R. (2016). Sistem Pendukung Keputusan Penentuan Karyawan Terbaik Menggunakan Metode AHP dan Topsis. Seminar Nasional Teknologi Informasi Dan Komuniikasi 2016 (SENTIKA 2016), 2(3), 440-445 [Online]. Available: https://fti.uajy.ac.id/sentika/publikasi/makalah/2016/82.pdf. [Accessed: 28Nov-2018]

[4] Kusrini. (2007). Konsep dan Aplikasi Sistem Pendukung Keputusan. Yogyakarta: Andi.

[5] Nardiono. (2017). Komparasi Metode Simple Additive Weighting ( SAW ) dan Metode Weighted Product ( WP ) dalam Menentukan Karyawan Terbaik ( Studi Kasus : Pt . Matrixnet Global Indonesia ). Jurnal Informatika Universitas Pamulang, 2(1), 25-33 [Online]. Available: openjournal.unpam.ac.id/index.php/informatika/article/view/1502. [Accessed: 28-Nov-2018]

[6] Nofriansyah, D. (2014). Konsep Data Mining vs Sistem Pendukung Keputusan. Yogyakarta: Deepublish.

[7] Pratiwi, H. (2018). Sistem Pendukung Keputusan. Yogyakarta: Deepublish.

[8] S R Pressman, B. R. M. (2015). Software Engineering - A Practitioner's Approach - Eigth Edition. USA: Mc. Graw Hill Education.

[9] Sari, F. (2018). Metode dalam Pengambilan Keputusan. Yogyakarta: Deepublish.

[10] Sunarti. (2018). Perbandingan Metode TOPSIS dan SAW untuk Pemilihan Rumah Tinggal. Journal of Information System, 3(1), 69-79 [Online]. Available: publikasi.dinus.ac.id/index.php/joins/article/download/1883/1289. [Accessed: 28-Nov2018]

[11] Suratmi. (2016). Analisa Perbandingan Metode Weighted Product (WP) dan Metode Analytical Hierarchy Process (AHP) untuk Menentukan Penerima Bonus pada Karyawan PT.Telesindo Shop. Jurnal Infotek, 1(3), 142-150 [Online]. Available: https://journal.unnes.ac.id/nju/index.php/sji/article/view/18050. [Accessed: 28-Nov-2018]

[12] Syafrianto, A. (2017). Penerapan Algoritma AHP dan SAW dalam Pemilihan Penginapan di Yogyakarta. Jurnal Ilmiah Data Manajemen Dan Teknologi Informasi (Dasi), 17(4), $7-12$.

[13] Tridhonanto. (2010). Meraih Sukses dengan Kecerdasan Emosional. Jakarta: Gramedia.

[14] Tsabit Rahman dkk. (2017). Analisis Model Pengambil Keputusan AHP dan TOPSIS Untuk memilih Software Berbasis Open Source Digital Library pada Universitas 
Janabadra. Seminar Nasional Inovasi Teknologi UN PGRI Kediri, 22 Februari 2017, 1(2), 441-450.

[15] Yasa, G. S. (2014). Bimbingan Belajar. Yogyakarta: Graha Ilmu. 